in the earlier years of their degree courses, and a particularly heavy commitment is what, in Great Britain, would correspond to Intermediate B.Sc. classes. For example, during the 1947 session laboratory facilities for some 2,100 such students had to be provided. Although by now (1951) this number has become approximately 1,100 , it is not expected to become smaller in the foreseeable future.

Indeed, from 1953 onwards, it is anticipated that enrolments at Australian universities will rise by perhaps 1,000 per annum until about 1958, and thereafter by about 2,000 per annum until they reach a peak in 1965. These forecasts are based partly on the jump of the Australian birth-rate occurring in the late 1930's following the depression, and upon the growing flow of migrants to the Dominion. Furthermore, it is hoped that many South-East Asian students will in the future go to Australia for higher education or postgraduate work. It is intended, therefore, to utilize the present benefaction to proceed as soon as possible with the erection of a sufficient part of the eventual building to accommodate the large group of elementary students just mentioned, and thus enable them to leave the present factory-like, fibro-cement, temporary laboratory they now occupy.

Cornpletion of a new Chemistry School must be necessarily dependent upon the provision of funds. It will be a development of benefit indirectly to a number of other departments of the University. These, at present working under extreme difficulties because of shortage of space and lack of modern facilities, will be able then to expand into much of the accommodation previously used by chemistry.

\section{VOLUME TABLES FOR ESTIMATING TIMBER IN GREAT BRITAIN}

$\mathrm{F}^{\mathrm{O}}$

$R$ a century and a half at least on the Continent of Europe, for example, in Germany and France, volume tables have been in existence which enabled the forester and the timber merchant to calculate the volume of timber in crops of standing trees of various age classes, without having actually to measure the crops. These tables were based on a large number of measurements of selected areas of the same age, situation and soil, and so forth, carried out over a number of years and in blocks of forest which had passed through more than one rotation of careful management.

In tropical forest regions the first attempt to prepare volume tables was begun in India. The difficulty here was that the forests were virgin ones and not regular crops grown by man for at least one rotation, and allowances had to be calculated and allowed for. The user of the table therefore had to make certain allowances to the figures of volumes contained in the table. The Forestry Commission has been undertaking work of this description in Great Britain, and last year it published general volume tables for oak, beech, Scots pine and European larch*;

* Forestry Commission. Forest Record No. 5: General Volume Table for Oak in Great Britain. By F. C. Hummel and W. T. Waters. Pp. 12. 4d, net. Forest Record No. 6: General Volume Table fo Beech in Great Britain By F. C. Hummel and W. T. Waters. Pp. 12 4d. net. Forest Record No. 8: General Volume Tables for Scots Pin in Great Britain. By F. C. Hummel, T. W. Irvine and J. Jeffers. Pp. 28. 9d. net. Forest Record No, 9: General Volume Tables fo European Larch in Great Britain. By F. C. Hummel, T. W. Irvine and J. Jeffers. Pp. 26. 9d. net. (London: H.M. Stationery Office, 1950.) other tables are promised for birch, Corsican pine, Japanese larch, Norway spruce, Sitka spruce and Douglas fir.

The volume tables for broad-leaved species, including the one for beech, give average hoppus (or 'cubic foot quarter-girth') volumes over bark for trees of a given breast-height quarter-girth (abbreviated as B.H.Q.G.) and timber hoight. Breast height is taken at $4 \mathrm{ft} .3 \mathrm{in}$. above ground level (on the upper side of the tree on slopes) and volumes are measured, in lengths coinciding with 'stops', from ground-level to timber height, that is, an over-bark top diameter of 5-6 in. or to the point where the stem loses itself in the crown, whichever comes first. A 'stop' is a point on the stem at which there is a sudden change in diameter or a pronounced bend. No allowance is made for the stump, and branch wood of all dimensions is ignored.

The volume tables are intended to assist foresters, landowners and others in estimating the cubic contents of standing timber; but, in order to achieve this purpose, their uses and limitations must be clearly understood. Trees with identical breastheight girths and heights may differ from one another in the rate of taper. The tables cannot therefore be relied upon to give accurate estimates of individual tree volumes; they can only be expected to give satisfactory estimates for the aggregate volumes of a group of trees or of a whole stand. Even whole stands may differ from one another in stem form, although usually in a lesser degree, and it is therefore always advisable when first using a general volume table under a given set of conditions to test it on a number of felled stems grown under those conditions. If the table shows a definite bias, volume table estimates of standing timbers on that site will have to be adjusted accordingly.

Unless a stand is very small, it is usually not necessary to apply the volume table to every single tree. In old hardwood stands it is probably best to measure the breast-height quarter-girth and to estimate the timber height of every $n$th tree, the value of $n$ being chosen so that there will be at least one hundred such trees; for example, if there are five hundred, every fifth tree would be measured. The volume of the stand is then obtained by multiplying the total volume of the measured trees by $n$. In young hardwood stands and conifer stands of all ages, in which stem.length varies less erratically, it is usually best to girth all trees in order to determine the mean girth-that is, the girth corresponding to the mean basal area of the stand-and then to measure the heights of a number of trees near that mean girth in order to get a mean height. The volume for this mean girth and height, as derived from the volume table, multiplied by the number of stems, gives an estimate of the standing volume of the crop.

When estimating the volume of standing timber in large stands or whole forests, these or similar methods will usually be applied, not to the whole area but only to a representative sample of it. It requires a knowledge of sampling theory and of local conditions to find the most efficient sampling technique in any particular case; but for many practical purposes and for working plan enumerations in particular, a ten per cent sample consisting either of parallel strips 1-1 chain wide or of small circular plots, spaced at regular intervals over the whole area, will often give efficient and unbiased estimates of adequate precision. 